\title{
THE IMPACT OF TEMPERATURES TO REDUCE THE RISK OF SALMONELLA ARIZONA AND SALMONELLA ENTERITIDIS IN TABLE EGGS
}

\author{
WALAA M.A. ELSHERIF and AZHAR M. HASSAN \\ Animal Health Research Institute, Assiut Regional Laboratory
}

\section{ABSTRACT}

Received at: $26 / 6 / 2013$

The prevention of salmonellosis is closely associated with food safety. So, in the present study A survey was conducted to determine the prevalence of Salmonella in 300 hen's eggs (commercial and balady) representing 150 eggs for each were collected randomly from Assiut city. Every 5 eggs represent one sample. From balady egg's shell $6.67 \%, 13.33 \% \mathrm{~S}$. arizona and $3.33 \%, 10 \% \mathrm{~S}$. enteritidis were recovered using S.S. (salmonella shigella) and XLD (Xylose Lysine Desoxycholate) agars, respectively. Salmonella arizona was detected in balady egg's content in percentage $0,6.67 \%$ while, S. enteritidis detected in 3.33 and $6.67 \%$ on the same media. Commercial farm hen eggs came secondary to Balady hen eggs. $S$. arizona and $S$. enteritidis could be detected on egg shell at a same percentage $3.33 \%$ on S.S. agar but on were XLD they isolated by $6.67,10 \%$, respectively. From egg content both microorganisms detected in $3.33 \%$ on both media but failed to detect S. enteritidis on S.S. agar. Serologically other Salmonellae detected were S. typhimurium, S.anatum and S. kentucky. S. arizona and $S$. enteritidis subjected in this study to antibiotic sensitivity test. Antibiotic resistance in relation to 9 antibiotics (Doxveto (Dov, 30 $\mathrm{gg}$ ), Lincomycin (L2, 2mcg), Novobiocin (NV30, 30mg), Neomycin (Neo, 30mcg), Amoxyveto (VMD, $5 \mathrm{mcg}$ ), Eryton (CIN, 15mcg), Ciprofloxacin (Cip, 5mcg), Cloxacillin (CX1, $1 \mathrm{mcg}$ ) and Cephradine (CE30, 5mcg) was studied. The results indicated that $S$. arizona and $S$. enteritidis were sensitive to Doxveto (Dov, $30 \mu \mathrm{g}$ ) and Novobiocin (NV30, 30mg) and resist to the remained antibiotics. This work was conducted to study the effect of different degree of temperatures on $S$. arizona and $S$. enteritidis in hen's eggs. The results indicated that $S$. arizona still found until the fifth week in the inoculated eggs with test organisms stored at $4{ }^{\circ} \mathrm{C}$, while $S$. enteritidis still found until the third week. While, after immersing the inoculated eggs with test organisms in boiling water bath for 10 and 15 minutes then cooled and examined the results indicated that complete destruction of $S$. arizona and $S$. enteritidis. It could be concluded that we must keep eggs refrigerated at all times and Eggs should be cooked at least ten minutes. The economic and public health importance of $S$. arizona and $S$. enteritidis that affect the human health through consumption of eggs were discussed. Likewise, suggestive measures for improving the quality of produced eggs and the suitable procedure to cook eggs are given.

Key words: Table eggs, Salmonella arizona, S. enteritidis.

\section{INTRODUCTION}

Despite of the extensive public health measures over the past century, Salmonella remains the second most commonly identified cause of bacterial foodborne disease in the developed countries and a signficant cause of morbidity and mortality in the developing world (WHO, 2002 and Amin, 2004). In Egypt salmonellae were found in 3\% cases of children diarrhea in rural areas and $4 \%$ in urban areas. In Upper Egypt, salmonellae were detected in $14.8 \%$ of cases of children diarrhea (FAO, 1993)
Table eggs which constitute several dishes or foods consumed and are considered cheap sources of protein, have served as vehicles for numerous enteropathogens (Adesiyun et al., 2007). Salmonella spp., particularly $S$. arizona and $S$. enteritidis have been most frequently associated with table eggs (Nygard et al., 2004). Table eggs contaminated by bacterial pathogens and consumed raw or improperly cooked have been responsible for many epidemics of gastroenteritis worldwide (Nunes et al., 2003). S. arizona is known to cause infection in reptiles and other animals. It is an uncommon human pathogen. Over the last 50 years, approximately 50 case reports and case series have been appeared (Cone et al., 
1990). S. enteritidis continued to be a major cause of illness and death. It is the most common serovar causing approximately $80 \%$ of foodborne salmonellosis cases (CDC, 2009). Moreover, it results in more deaths than any other pathogen (Olsen and Hammack, 2000).

A variety of foods and environmental sources harbor bacteria that are resistant to one or more antimicrobial drugs used in human or veterinary medicine and in food-animal production (Anderson et al., 2003 and Schroeder et al., 2004). Though many bacteria recovered from poultry or poultry-related samples have been monitored, few published studies have reported on antimicrobial resistance in bacteria, particularly Salmonella recovered from shell eggs (Chung et al., 2004 and Dias de Oliveira et al., 2005). So in our study try to monitor the antibiotic susceptibility of isolates.

Moreover, Salmonella penetration can occur either after lay (most likely) or at later stages in the distribution chain, if eggs are subject to environmental changes resulting in temperature differential across the shell, or condensation. Certain combinations of temperature and $\mathrm{RH}$ can lead to condensation on the eggshell, and influence survival, penetration and growth of Salmonella (Radkowski, 2002). Messens et al. (2007) provided that the cold chain is maintained, commencing cooling at farm level has the highest beneficial effect with regard to the control of the growth of Salmonella. Also, survival behaviors of heat shocked cells of these pathogens by applying different temperatures were studied by several investigators (Bradshaw et al., 1990 and Korashy et al., 2008).

So, the present work aimed to isolate $S$. arizona and $S$. enteritidis from hen's eggs (commercial and balady), study the antibiotic susceptibility of isolates and to control the infection through study the effect of refrigerator temperature on isolates for storage and different temperatures during hen's egg preparation for consumption.

\section{MATERIALS and METHODS}

\section{A- Collection of samples:}

300 of fresh hen eggs of native breeds (Balady) and poultry farms (commercial) (150 for each) bought from different groceries in Assiut city. Every 5 eggs constitute one group.

\section{B- Preparation of samples:}

Egg shells were tested by rinse for shell surfaces as described by Moats (1980). Egg contents were prepared and evacuated according to Speck (1984).

\section{C- Isolation of Salmonella spp. from egg samples} Samples were pre-enriched on Rappaport-Vassiliadis (RV) broth at $37^{\circ} \mathrm{C}$ for 24 hours (Wallace et al., 2009). S.S. agar and XLD agars were used to isolate Salmonella spp. according to Andrews and Hammack (2001) and Wallace et al. (2009). Pink colonies with black center on S.S. agar as well as yellow colonies with or without black centers colonies on XLD agar were identified as Salmonella spp. by Gram stain and various biochemical tests as described by Andrews and Hammack (2001) and ISO-6579: 2002 standard. Modification of the confirmatory process indicated by FDA $(1995,2002)$ protocols was done.

\section{D-Serological identification of Salmenollae species:}

Isolates proved biochemically to be Salmonella spp. were subjected to serological identification according to Kauffmann white scheme (Kauffmann, 1974) by using rapid diagnostic Salmonella antiserum sets. Isolates were sub-cultured on nutrient slope for 24 hours at $37^{\circ} \mathrm{C}$ for application of slide agglutination technique, two homogenous suspensions were made on a slide by suspending a piece of suspected colony in a drop of sterile physiological saline. A drop of each of separate $\mathrm{O}$ and $\mathrm{H}$ Salmonella factors were added separately to each of the suspensions with standard loop thoroughly mixed to bring the microorganisms in close contact with antisera. Positive agglutination occurred within a minute and could be easily seen with the naked eye. A delayed or partial agglutination was considered as negative or false result.

\section{Determination of $O$ (somatic) antigens:}

Separate O antisera were applied to determine the group of the Salmonella isolates.

\section{Determination of $\mathbf{H}$ (flagella) antigens:}

Polyvalent $\mathrm{H}$ antisera for both phase $\mathrm{I}$ and phase 2 were tried in order to determine the complete antigenic formula of the isolates.

\section{E- Antibiotic susceptibility test}

$S$. arizona and $S$. enteritidis isolates were tested for antibiotic resistance using the standard disc diffusion method (NCCLS, 1993). Discs containing Doxveto (Dov, 30 $\mu \mathrm{g}$ ), Lincomycin (L2, 2mcg), Novobiocin (NV30, 30mg), Neomycin (Neo, 30mcg), Amoxyveto (VMD, 5mcg), Eryton (CIN, 15mcg), Ciprofloxacin (Cip, 5mcg), Cloxacillin (CX1, 1mcg) and Cephradine (CE30, 5mcg) were used. The multiple antibiotic resistance (MAR) index for each isolate was determined, it was defined as $a / b$, where $a$ is the number of antibiotics to which a particular isolate is resistant and $b$ is the number of antibiotics to which the isolates is exposed (Adesiyun et al., 2007). 


\section{D- Effect of different temperatures on $S$. arizona and $S$. enteritidis inoculated in eggs:-}

(Chantarapanont et al., 2000; Korashy et al., 2008 and EFSA, 2009):

The tested strains were purified and inoculated into brain heart infusion broth and overnight incubated. For $0.1 \mathrm{ml}$ of the incubated broth, sterile saline was added to bring turbidity to $0.5 \mathrm{McF}$. Pervious suspension is the standard strain suspension of which $1 \mathrm{ml}$ may contain approximately about 1x105 CFU (Quinn et al., 1994).

Preparation of an egg for inoculation by the test organisms:
A small hole was made at the blunt end of an egg with a sterile drill. Aseptically injection of an inoculum $(1 \mathrm{ml})$ containing $1 \times 10^{5}$ c.f.u of the tested organism into the egg yolk by a sterile needle. Then the hole is covered after injection by Ducocement.

1- Cooling: The inoculated eggs with test organisms were stored at $4{ }^{\circ} \mathrm{C}$ until deterioration of eggs which detected by testes of freshness of egg (candle lamp and dipping in water bath).

2- Boiling: The inoculated eggs with test organisms were immersed in boiling water bath for 10 and 15 minutes then cooled and examined.

\section{RESULTS}

The results were illustrated in the following Tables

Table 1: Incidence of Salmonella spp. in the examined Balady hen's eggs samples:

\begin{tabular}{|c|c|c|c|c|c|c|c|c|c|c|}
\hline \multirow{2}{*}{ Samples } & \multirow[t]{2}{*}{$\begin{array}{c}\text { No. of } \\
\text { examined } \\
\text { samples }\end{array}$} & \multirow[t]{2}{*}{ Media used } & \multicolumn{2}{|c|}{$\begin{array}{c}\text { Presumptive } \\
\text { Salmonella colonies }\end{array}$} & \multicolumn{2}{|c|}{$\begin{array}{c}\text { Positive } \\
\text { Salmonella spp. } \\
\text { serologically } \\
\end{array}$} & \multicolumn{2}{|c|}{ S. arizona } & \multicolumn{2}{|c|}{ S. enteritidis } \\
\hline & & & No. & $\%$ & No. & $\%$ & No. & $\%$ & No. & $\%$ \\
\hline \multirow[t]{2}{*}{ Egg shell } & 30 & S.S.agar & 10 & 33.3 & 5 & 16.67 & 2 & 6.67 & 1 & 3.33 \\
\hline & & XLD agar & 14 & 46.67 & 8 & 26.67 & 4 & 13.33 & 3 & 10 \\
\hline \multirow{2}{*}{$\begin{array}{l}\text { Egg } \\
\text { content }\end{array}$} & 30 & S.S.agar & 8 & 26.67 & 3 & 10 & 0 & 0 & 1 & 3.33 \\
\hline & & XLD agar & 12 & 40 & 6 & 20 & 2 & 6.67 & 2 & 6.67 \\
\hline
\end{tabular}

Table 2: Incidence of Salmonella spp. in the examined commercial hen's eggs samples:

\begin{tabular}{|c|c|c|c|c|c|c|c|c|c|c|}
\hline \multirow{2}{*}{ Samples } & \multirow[t]{2}{*}{$\begin{array}{c}\text { No. of } \\
\text { examined } \\
\text { samples }\end{array}$} & \multirow[t]{2}{*}{ Media used } & \multicolumn{2}{|c|}{$\begin{array}{c}\text { Presumptive } \\
\text { Salmonella colonies }\end{array}$} & \multicolumn{2}{|c|}{$\begin{array}{c}\text { Positive } \\
\text { Salmonella spp. } \\
\text { serology } \\
\end{array}$} & \multicolumn{2}{|c|}{ S. arizona } & \multicolumn{2}{|c|}{$\begin{array}{l}S . \\
\text { enteritidis }\end{array}$} \\
\hline & & & No. & $\%$ & No. & $\%$ & No. & $\%$ & No. & $\%$ \\
\hline \multirow[t]{2}{*}{ Egg shell } & 30 & S.S.agar & 8 & 26.67 & 5 & 16.67 & 1 & 3.33 & 1 & 3.33 \\
\hline & & XLD agar & 11 & 36.67 & 8 & 26.67 & 2 & 6.67 & 3 & 10 \\
\hline \multirow{2}{*}{$\begin{array}{l}\text { Egg } \\
\text { content }\end{array}$} & 30 & S.S.agar & 9 & 30 & 4 & 20 & 1 & 3.33 & 0 & 0 \\
\hline & & XLD agar & 13 & 43.33 & 8 & 26.67 & 1 & 3.33 & 1 & 3.33 \\
\hline
\end{tabular}


$\underline{\text { Assiut Vet. Med. J. Vol. } 59 \text { No. } 138 \text { July } 2013}$

Table 3: Frequency distribution of different isolated Salmonella strains in the positive hen's egg samples based on their serological identification.

\begin{tabular}{lccccccccc}
\hline & \multicolumn{3}{c}{ Balady eggs } & \multicolumn{3}{c}{ Commercial eggs } \\
\cline { 2 - 11 } Isolated Salmonella strains & \multicolumn{2}{c}{ Egg shell } & \multicolumn{2}{c}{ Egg content } & \multicolumn{2}{c}{ Egg shell } & \multicolumn{2}{c}{ Egg content } \\
\cline { 2 - 11 } & SS & XLD & SS & XLD & SS & XLD & SS & XLD \\
\hline Salmonella arizona & 2 & 4 & 0 & 2 & 1 & 2 & 1 & 1 \\
\hline Salmonella enteritidis & 1 & 3 & 1 & 2 & 1 & 3 & 0 & 1 \\
\hline Salmonella typhimurium & 1 & 0 & 2 & 2 & 0 & 1 & 0 & 2 \\
\hline Salmonella anatum & 1 & 0 & 0 & 0 & 2 & 2 & 2 & 1 \\
\hline Salmonella kentucky & 0 & 1 & 0 & 0 & 1 & 0 & 1 & 3 \\
\hline Total & 5 & 8 & 3 & 6 & 5 & 8 & 4 & 8 \\
\hline
\end{tabular}

Table 4: Antibiotic sensitivity tests for S. arizona and S. enteritidis

\begin{tabular}{|c|c|c|c|}
\hline Drug used & MAR index & Drug sensitivity pattern & \\
\hline Amoxyveto VMD & Non & & Resist \\
\hline Cephradine CE30 & Non & & Resist \\
\hline Ciprofloxacin Cip & Non & & Resist \\
\hline Cloxacillin $\quad \mathbf{C x 1}$ & Non & & Resist \\
\hline Doxveto & 2.3 & sensitive & \\
\hline Eryton Cin & Non & & Resist \\
\hline Lincomycin $\quad$ L2 & Non & Resist & \\
\hline Neomycin Neo & Non & & Resist \\
\hline Novobiocin NV30 & 2.3 & sensitive & \\
\hline
\end{tabular}

Table 5: Results of effect of different temperatures on $S$. arizona and $S$. enteritidis inoculated in eggs

\begin{tabular}{|c|c|c|c|}
\hline \multirow{2}{*}{ Temperature } & \multirow{2}{*}{ Duration } & \multicolumn{2}{|c|}{ Survival of organisms } \\
\hline & & S. arizona & S. enteritidis \\
\hline \multirow{7}{*}{ Cooling } & 1st day & + & + \\
\hline & $3 r d$ day & + & + \\
\hline & 1 week & + & + \\
\hline & 2nd week & + & + \\
\hline & $3 r d$ week & + & + \\
\hline & 4th week & + & - \\
\hline & 5th week & + & - \\
\hline \multirow{2}{*}{ Boiling } & $10 \mathrm{~min}$. & - & - \\
\hline & $15 \mathrm{~min}$. & - & - \\
\hline
\end{tabular}




\section{DISCUSSION}

Salmonellosis is a foodborne infection of major economic importance. Contamination of table eggs with Salmonella, especially S. arizona and S. enteritidis, is a major health concern worldwide (Lublin and Sela, 2008). The present study showed that presumptive salmonella colonies using SS and XLD agar were 33.3, 46.67\% from egg shell and 26.67, 40\% from egg content of balady hen's egg, respectively (Table,1). While, from farm hen's egg shell presumptive salmonella colonies were 26.67, $36.67 \%$ and from content were $30,43.33 \%$ on both media, respectively (Table 1,2). Salmonella spp. were previously isolated from egg samples in percentage $22.9 \%$ by Jean et al. (1995); Adesiyun et al. (2007) and $26.1 \%$ by Adesiyun et al. (2005) and Indar et al. (1998) from shell and content of table eggs. This may be attributed to the chickens carry the Salmonella in their own bodies, and pass Salmonella along to the yolk and white while the egg is forming in the ovaries. Chickens can also pass bacteria to the eggshell - and through the shell pores into the inner egg - when the egg is laid. Chickens can harbor Salmonella without being sick themselves. Salmonellae are frequently isolated from various farm environments such as water, feed, and manure. Moreover, asymptomatic shedding of Salmonella in feces of hens also occur so there is a risk of the pathogen reaching to eggs through fecal contamination (Troutt et al., 2001 and Huston et al., 2002). According to the European Commission (2003), eggs and products containing raw eggs are among the food categories most likely to pose the greatest risk to public health in relation to salmonellosis. In 2007, the reported number of cases and incidence of human salmonellosis in the EU were, respectively, 154,099 cases and 31.1 cases per 100,000 inhabitants (EFSA, 2009). Eggs and egg products were the most frequently reported source of foodborne outbreaks caused by Salmonella in 2006 (EFSA, 2007). S. enteritidis is the serovar causing more than $60 \%$ of the human Salmonella infections in the EU (EFSA, 2009), and also most often associated with egg borne infections (WHO, 2001).

The incidence of infection with $S$. enteritidis via hen eggs has increased in many countries (Yukiko et al., 2001) and the risk of $S$. arizona increased through consumption of table egg. On the basis of biochemical and serological methods for identification of the isolates we found that $S$. arizona could be detected in balady hen's egg shell in percentage $6.67,13.33 \%$ and from egg content 0 , $6.67 \%$ by SS and XLD agar, respectively. and 3.33, $6.67 \%$ from egg shell, 3.33, 3.33\% from egg content of commercial hen's egg (Table1,2). The low number of confirmed positive isolates compared with the total number of suspected colonies indicates that the identification of Salmonella should not based solely upon the morphological characters of suspected colonies on differential media (Abdel-hameid, 2013). Siebeling (1975), D'Aoust et al. (1990) and Sechter (1996) could detect S.arizona infection from fresh eggs.

In the United States $S$. enteritidis is the second most commonly isolated serotype from human illness, and is known to be strongly associated with shell eggs and egg containing products. Eggs can become contaminated internally either by penetration through the shell or directly during formation in the reproductive tract (Zoe et al., 2012). In our study, $S$. enteritidis could be detected in egg shell of both balady and commercial hen's egg in the same percentage $3.33,10 \%$ and from content of $3.33,6.67 \%$ of balady and $0,3.33 \%$ of commercial hen's egg by S.S. and XLD agar, respectively (Tables 1,2). $S$. enteritidis has been isolated from the yolk, albumen, and shell of naturally infected intact eggs by S.S. agar (Jean et al., 1995). Yukiko et al. (2001) detected S. entertidis in 12/15 samples of naturally contaminated liquid egg and in 37/39 samples shell egg using XLD agar. Higher percentage of $S$. enteritidis could be isolated by Gantois et al. (2008); Lucía et al. (2012) (25\%).

According to information gathered from 84 countries responding to a global survey conducted by the World Health Organization (WHO), S. enteritidis and S. typhimurium accounted for $70 \%$ of all human and nonhuman isolates of salmonella reported worldwide between 1995 and 2008 (CDC, 2009). More than 2,500 Salmonella serovars have been identified according to the serospecificities of the somatic and flagellar antigens. Some serovars, exemplified by Salmonella enterica serovar Typhimurium and $S$. enteritidis, can infect a broad range of hosts (Geimba et al., 2004). Corresponding Table 3, it is persisted that the different identified strains of salmonella via sero-typing technique other than $S$. arizona and $S$. enteritidis were $S$. typhimurium, $S$. anatum and $S$. Kentucky in different percentages. Although, there are relatively low numbers of positive samples in this study, the pathogen represent a potential risk to consumers on the basis that all salmonellae are potentially pathogenic (Zansky et al., 2002).

A prevalence of $22.9 \%$ for resistance to antimicrobial agents detected amongst Salmonella isolates from eggs is considerably lower than the prevalence of $50 \%$ reported for Salmonella isolates recovered from livestock in Trinidad (Adesiyun et al., 1993). So, the antimicrobial resistance testing is highly discriminatory and might also give helpful information towards an effective therapy. Antibiotics used in this study represented the major groups of antibiotics used. The result of this test showed that both $S$. arizona and $S$. enteritidis were sensitive to 
Doxveto (Dov, 30 $\mu \mathrm{g}$ ) and Novobiocin (NV30, 30mg) and resist to the remained antibiotics (Table 4). Similarly, the prevalence of resistance, as determined by resistance to one or more antimicrobial agents detected by Bajaj et al. (2003); NARMS (2005) and Musgrove et al. (2006), although higher than reported for isolates from table eggs by Brown et al. (1994) is significantly lower than found in Brazil (Simango and Mbewe, 2000). It has been reported that inappropriate use of antimicrobial agents in livestock may result in the development of resistance amongst bacteria in these animals or their products (Washington, 1979; Waltner-Toews and McEwen, 1994).

MAR index values of $>0.2$ are considered indicators of high-risk source of selective pressure for the development of antibiotic resistance bacteria (Krumperman, 1983). So, it is necessary to consider the resistance pattern of the Salmonella in question before administering any antibiotic.

As seen, high level of multi drug resistance of the $S$. arizona and $S$. enteritidis strains isolated from both types of egg samples is of concern to public health so, maintenance of proper cleanliness and hygiene during handling to limit the degree of contamination is essential together.

Eggs are one among the major animals foods mostly marketed raw and frequently consumed raw, semiraw in many dishes and form an important part of meals contain raw eggs as an essential ingredient (homemade ice cream, mayonnaise, eggnog etc.). These dishes are not heated up to the (FAO, 1979) recommended temperatures, $155^{\circ} \mathrm{F}$ for at least 15 seconds (Mermelstein, 2001) and this is not enough to render an egg free from pathogenic organisms as yolk is high nutritive medium permits multiplication of the organisms. Several methods of microbial destruction were discussed by Serrano et al. (1997) and Brackett et al. (2001). Table 5 clarified that cooling storage not effective on $S$. arizona and $S$. enteritidis if contaminate egg from beginning also, that in similar with (Baker, 1990; Radkowski, 2002; Messens et al., 2006).

Braun and Fehlhaber (1995) observed that Salmonella can be found in the egg yolk within 1 or 2 days at $20^{\circ} \mathrm{C}$ and $30^{\circ} \mathrm{C}$ but also within 14 days at $7^{\circ} \mathrm{C}$. But, boiling procedure used for destruction of the inoculated test organisms is enough at 10 and15 minutes. The results came in line with Baker et al. (1983); Schuman et al. (1997); Soliman and El-Tabiy (2007) and (Korashy et al., 2008).

The obtained results recommended that boiling must be adopted for more than 10 minutes to ensure complete destruction of pathogens may contaminate eggs. Heat treatment - time temperature conditions aims to achive a decrease in the number of viable organisms (Stadelman et al., 1996 and Schuman et al., 1997).

There is a considerable demand for using high temperatures during cooking of eggs to destroy the present pathogens. Gossett and Baker (1981) studied the textural problems and greenish discoloration which affected eggs due to high temperatures used and suggested the addition of citric acid which gives favorable effects due to thermal destruction of microorganisms.

So, in order to remove or reduce the risk of some of pathogenic organisms of public health importance contaminate eggs, there are several points must be adopted. Chosen of healthy mother's hens are necessary to obtain eggs of free pathogens. Hygienic measures applied in the farms during handling and storage. Using of hot soapy water with those come in contact with eggs and egg containing foods in work areas. Eggs must be held at low temperature $\left(5^{\circ} \mathrm{C}\right)$ to prevent proliferation of the pathogens. Cleaning with sanitizer minimizes the contamination of the shells, beside pasteurization of egg products as statutory requirements in many countries. Educational programs for consumers informed the risks resulted from eating under cooked eggs particularly the elderly and immune-compromised persons who are more susceptible to infection.

\section{REFERENCE}

Abdel-hameid, Zeinab. M. (2013): Assessment of the hygienic quality of market cream in Assiut city. Ph.D. thesis. Faculty of veterinary medicine. Assiut university.

Adesiyun, A.A.; Kaminjolo, J.S.; Loregnard, R. and Kitson-Piggott, W. (1993): Epidemiology of Salmonella infections in Trinidadian livestock farms. Revue d'Elevage et de Medecine Veterinaire des Pays Tropicaux, 46: 435-437.

Adesiyun, A.N.; OYah, A.N.; Seepersadsingh, A.S.; Rodrigo, V.; Lashley, L. and Musai. (2007): Antimicrobial resistance of Salmonella spp. and Escherichia coli isolated from table eggs Food Control 18: 306-311.

Adesiyun, A.; Offiah, N.; Seepersadsingh, S.; Rodrigo, V.; Lashley, L.; Musai and Georges, $K$. (2005): Microbial health risk posed by table eggs in Trinidad. Epidemiology and Infection, 133, 1049-1056.

Amin, Walaa, F. (2004): Some studies on salmonella species in milk and some milk products in Assiut City. M. V.Sc. Thesis Fac. Vet. Med. Assiut Univ. Egypt.

Anderson, A.D.; Nelson, J.M.; Rossiter, S. and Angulo, F.J. (2003): Public health consequences of use of antimicrobial agents in food animals in the United States. Microb. Drug Resist. 9: 373-379. 
Andrews, W.A. and Hammack, T.S. (2001): Bacteriological. Analytical Manual on line. U. S. Food and Drug Administration. Center for Food Safety and Applied Nutrition.

Baker, R.C. (1990): Survival of Salmonella Enteritidis on and in shelled eggs, liquid eggs and cooked egg products. Dairy, Food and Environmental Sanitation 10: 273-275.

Baker, R.C.; Hogartv, W.P. and Vadehra, D.V. (1983): Survival of Salmonella typhimurium and Staphylococcus aureus in Eggs cooked by different methods. Poultry Science. 62: 1211-1216.

Bajaj, B.K.; Sharma, V. and Thakur, R.L. (2003): Prevalence and antibiotic resistance profiles of Salmonella spp. in poultry eggs. J. Food Sci. Technol. 40: 682-684.

Brackett, R.E.; Schman, J.D.; Ball, H.R. and Scouten, A.J. (2001): Thermal inactivation Kinetics of Salmonella spp. Within intact egg heated using humidity controlled air. J. Food Prot., 64 (7): 934-938.

Bradshaw, J.G.; Shah, D.B.; Forney, E. and Madden, J.M. (1990): Growth of Salmonella Enteritidis in yolk of shell eggs from normal and seropositive hens. J. Food Prot. 53 (12): 1033-1036.

Braun, P. and Fehlhaber, K. (1995): Migration of Salmonella Enteritidis from the albumen into the egg yolk. Int. J. Food Microbiol. 25 (1): 95-99.

Brown, D.J.; Baggesen, D.L.; Hansen, H.B.; Hansen, H.C. and Bisgaard, M. (1994): The characteristics of Danish isolates of Salmonella Enterica serovar Enteritidis by phage typing and plasmid proWling: 1980-1990. Acta Pathologica, Microbiologica et Immunologica Scandinavica, 102: 208-214.

CDC "Centers for Disease Control and Prevention" (2009): Salmonella surveillance: annual summary, 2006. U.S. Department of Health and Human Services, CDC, Atlanta, GA.http://www.cdc.gov /ncidod/dbmd/ phlisdata/salmonella.htm.

Chantarapanont, W.; Slutsker, L.; Tauxe, V. and Beuchat, L.R. (2000): Factors Influencing inactivation of Salmonella enteritidis in hard cooked eggs. J. Food Prot. 1: 36-43.

Chung, Y.H.; Kwon, Y.I.; Kim, S.Y.; Kim, S.H.; Lee, B.K. and Chang, Y.H. (2004): Antimicrobial susceptibilities and epidemiological analysis of Salmonella enteritidis isolates in Korea by phage typing and pulsed-field gel electrophoresis. J. Food Prot. 67: 264-270.

Cone, L.A.; Boughton, W.H.; Cone, L.A. and Lehv, L.H. (1990): Rattlesnake capsule-induced Salmonella arizonae bacteremia. West J. Med. 153:315-316.

D'Aoust, J.Y.; Daley, E.; Crozier, M. and Sewell, A.M. (1990): Pet turtles: A continuing international threat to public health. Am. J. Epidemiol. 132: 233-238.

Dias de Oliveira, S.; Siqueira Flores, F.; Ruschel dos Santos, L. and Brandelli, A. (2005): Antimicrobial resistance in Salmonella enteritidis strains isolated from broiler carcasses, food, human and poultry-related samples. Int. J. Food Microbiol. 97: 297-305.

EFSA "European Food Safety Authority "(2007): Report of the Task Force on zoonoses data collection on the analysis of the baseline study on the prevalence of Salmonella in holdings of laying hen flocks of Gallus gallus. The EFSA Journal: 97 pages.

EFSA "European Food Safety Authority" (2009): The Community Summary Report on trends and sources of zoonoses and zoonotic agents in the European Union in 2007. The EFSA Journal: 957: 1-29.

European Commission (2003): Opinion of the Scientific Committee on Veterinary Measures relating to Public Health on Salmonellae in foodstuffs. http://ec.europa.eu/food/fs/sc/scv/ out66_en.pdf. (accessed 26 January 2009).

FDA (1995): FDA Bacteriological Analytical Manual. Arlington, V A: Association \& Official Analytical Chemists.

FDA (2002): FDA Bactriological Analytical Manual, 8thed. washington, DC: US Food and Drug Administration (http://www.vm.cfsan.fda.gov/ webam/bam-s.html).

FAO (Food and Agriculture Orgainzation) (1993): Zoonotic diseases in the Near East Region Regional Office of the Unitied Nations, Cairo.

FAO. (Food and Agriculture Orgainzation) (1979): Manuals of Food Quality Control (4microbiological analysis) Rome.

Gantois, I.; Ducatelle, R.; Pasmans, F.; Haesebrouck, $F$. and Van Immerseel, $F$. (2008): Salmonella enterica Serovar Enteritidis Genes Induced during Oviduct Colonization and Egg Contamination in Laying Hens. Applied and Environmental Microbiology.74 (21):p. 6616-6622.

Geimba, M.P.; Tondo, E.C.; Oliveira, F.A.; Canal, C.W. and Brandelli, A. (2004): Serological characterization and prevalence of spvR genes in Salmonella isolated from foods involved in outbreaks in Brazil. J. Food Prot., 67: 1229-1233.

Gossett, P.W. and Baker, R.C. (1981): Prevention of green - gray discoloration in cooked liquid whole eggs. J. Food Sci. 46: 328-331.

Huston, C.L.; Wiltum, T.E.; Love, B.C. and keen, J.E. (2002): Prevalence of fecal shedding of Salmonella spp. in dairy herds. J. Am. Vet. Med. Assoc. 220: 645-649.

Indar, L.; Baccus-Taylor, G.; Commissiong, E.; Prabhakar, P. and Reid, H. (1998): Salmonellosis in Trinidad: evidence for 
transovarian transmission of Salmonella in farm eggs. West Indian Med. J; 47: 50-53.

Jean, L.S.; Kathleen, A.G.; Jodi, L.M. and Amy, C.L. (1995): Growth and penetration of Salmonella enteritidis, Salmonella heidelberg and Salmonella typhimurium in eggs. Wong International Journal of Food Microbiology. 24: $385-396$

Kauffmann, G. (1974): Kauffmann white scheme. J. Acta. Path. Microbiol. Sci., 61: 385.

Korashy, Eman A.; Wahba, Nahed M. and Hassanein, R. (2008): Public health hazards of some bacterial pathogens associated with consumption of eggs and studying the best cooking methods for their destruction. Assiut Vet. Med. J. Vol. 54 No. 117.

Krumperman, P.H. (1983): Multiple antibiotic resistance indexing of Escherichia coli to identify high risk sources of fecal contamination of foods. Appl. Environ. Microbiol. 46: 165-170.

Lublin, A. and Sela, S. ( 2008): The Impact of Temperature During the Storage of Table Eggs on the Viability of Salmonella enterica Serovars Enteritidis and Virchow in the Eggs Poultry Science. 87: 2208-2214.

Lucía, Y.; Laura, B.; Aracı' Martinez; Gerardo, G.; Clare, B.; Duncan, M. and Jose, A. (2012): Differential Phenotypic Diversity among Epidemic-Spanning Salmonella enterica Serovar Enteritidis Isolates from Humans or Animals. Applied and Environmental Microbiology. 76 (20): 6812-6820.

Mermelstein, N.H. (2001): Pasteurization of Food of shell eggs Food Technology. December, 72: 73-79.

Messens, W.; Grijspeerdt, K.; De Reu, K.; De Ketelaere, B.; Mertens, K.; Bamelis, F.; Kemps, B.; De Baerdemaeker, J.; Decuypere, E. and Herman, L. (2007): Eggshell penetration of various types of hens' eggs by Salmonella enterica serovar Enteritidis. J. Food Prot. 70 (3): 623-628.

Messens, W.; Grijspeerdt, K. and Herman, L. (2006): Eggshell penetration of hen's eggs by Salmonella enterica serovar Enteritidis upon various storage conditions. Br. Poult. Sci 47 (5): 554-560.

Moats, W.A. (1980): Classification of bacteria from commerical egg washers and washed and unwashed eggs. J. Appl. Environ. Microbiol. 4: 710-714.

Musgrove, M.T.; Jones, D.R.; Northcutt, J.K.; Cox, N.A.; Harrison, M.A.; Fedorka-Cray, P.J. and Ladely, S.R. (2006): Antimicrobial Resistance in Salmonella and Escherichia coli Isolated from Commercial Shell Eggs. Poultry Science 85: $1665-1669$

NARMS "National Antimicrobial Resistance Monitoring System" (2005): Subject: NARMS
data.http://www.ars.usda.gov/Main/ docs. htm? docid=6750 Accessed Dec. 2005.

NCCLS (National Committee for Clinical Laboratory Standards) (1993): Performance standards for antimicrobial disk susceptibility tests: 13, 24 NCCLS Doc. M2-A5. National Committee for Clinical Laboratory Standards, Vallinova, $\mathrm{Pa}$.

Nunes, I.A.; Helmuth, R.; Schroeter, A.; Mead, G.C.; Santos, M.A. and Solari, C.A. (2003): Phage typing of Salmonella Enteritidis from diVerent sources in Brazil. Journal of Food Protection, 66, 324-327.

Nygard, K.; de Jong, B.; Guerin, P.J.; Andersson, Y.; Olsson, A. and Giesecke, J. (2004): Emergence of new Salmonella Enteritidis phage types in Europe? Surveillance of infections in returning travelers. BMC Medicine, (2): 32.

Olsen, A.R. and Hammack, T.S. (2000): Isolation of Salmonella spp. from the housefly, Musca domestica L., and the dump fly, Hydrotaea aenescens (Wiedemann) (Diptera: Muscidae), at caged-layer houses. Journal of Food Protection, 63, 958-960.

Quinn, P.J.; Carter, M.S.; Markyl, B. and Carter, G.R. (1994): Clinical. Vet. Microbiology. Mosby-Year Book Europe Limited.

Radkowski, M. (2002): Effect of moisture and temperature on survival of Salmonella Enteritidis on shell eggs. Archiv fuer Gefluegelkunde 66: 119-123.

Schroeder, C.M.; White, D.G. and Meng, J. (2004): Retail meat and poultry as a reservoir of antimicrobial-resistant Escherichia coli. Food Microbiol. 21: 249-255.

Schuman, J.D.; Shelaon, B.W.; Vandepopuliere, J.M. and Ball, H.R. (1997): Immersion heat treatments for inactivation of Salmonella enteritidis with intact eggs. J. Appl. Microbiol. 83: 438-444.

Sechter, I. (1996): Arizona isolates in Israel. Ann Inst Pasteur (Paris) 119:323.

Serrano, L.E.; Murano, E.A.; Shenoy, K. and Olson, D.G. (1997): D values of Salmonella enteritidis isolates and quality attributes of shell eggs and liquid whole eggs treated with irradiation. Poult. Sci. 76: 202-205.

Siebeling, R.J.; Philip, M.; Neal, W. and David, G. (1975): Treatment of Salmonella-ArizonaInfected Turtle Eggs with Terramycin and Chloromycetin by the TemperatureDifferential Egg Dip Method. Applud Microbiology, 30 (5): 791-799

Simango, C. and Mbewe, C. (2000): Salmonella Enteritidis diarrhea in Harare, Zimbabwe. Tropical Medicine and International Health, 5: 503-506.

Soliman, Zienab, I. and El-Tabiy, Azza, A. (2007): A study on effect of immersion heat treatment on viability of Salmonella enteritidis in table eggs. Assiut Vet. Med. J. 53 (115). 
Speck, M.L. (1984): Compendium Method for Microbiological Examination of Food. American Public Health Association, Washington, D.C.

Stadelman, W.J.; Singh, R.K.; Muriana, P.M. and Hou, H. (1996): Pasteurization of eggs in the shell. Poult. Sci. 75: 1122-1125.

Troutt, H.F.; Galland, J.C.; Osburn, B.I.; Brewer, R.L.; Braun, R.K.; Schmitz, J.A.; Seras, P.; Childers, A.B.; Richey, E.; Mather, E.; Gibson, M.; Marthy, K. and Hogue, A. (2001): Prevalence of Salmonella spp. in cull (market) dairy cows at slaughter, J. Am. Vet. Med. Assoc. 219: 1212-1215.

Wallace, H.; Andrews; Andrew Jacobson and Thomas Hammack (2009): Bacteriological Analytical Manual. Salmonella. Ch. 5 November 2011 Version.

Waltner-Toews, D. and McEwen, S.A. (1994): Residues of antibacterial and antiparasitic drugs in foods of animal origin: a risk assessment. Preventive Veterinary Medicine, 20: 219-234.

Washington, J.A. (1979): The effects and significance of sub-minimal inhibitory concentrations of antibiotics. Review in Infectious Diseases, 1: 781-786.

WHO 'World Health Organisation' (2001): Surveillance programme for control of foodborne infections and intoxications in Europe. Seventh Report, 1993-1998. pp. 415-423.

WHO "World Health Organization" (2002): First pan- European conference on food quality and safety: Foodborne diseases are on the rises in Europe - FAO - WHO call for better consumer protection.

Yukiko Hara-Kudo; Susumu Kumagai; Takashi Masuda; Koukichi Goto; Kayoko Ohtsuka; Hiroyuki Masaki; Hiroyuki Tanaka; Kenji Tanno; Michiko Miyaharaf and Hirotaka Konuma (2001): Detection of Salmonella enteritidis in shell and liquid eggs using enrichment and plating. International Journal of Food Microbiology. 64: 395-399

Zansky, S.; Wallace.; Schoon maker - Bopp, D.; Smith, P.; Ramsey, F.; Painter, J.; Gupta, A.; Kalluri, P. and Noviello, S. (2002): From the Centers for Disease Control and Prevention. Outbreak of multidrug resistant Salmonlla newport. USA: JAMA 288: 951-953.

Zoe, R.H.; Corliss A. O'Bryan; Philip, G.C. and Steven, C.R. (2012): Salmonella Enteritidis in shell eggs: Current issues and prospects for control. Food Research International. 45: $755-764$.

تأثير درجات الحرارة المختلفة للحد من خطورة السالمونيلا اريزونا والسالمونيلا انتريتيذز فى البيض التجارى

$$
\text { ولاء محمود على الشريف ، ازهار محمد حسن }
$$

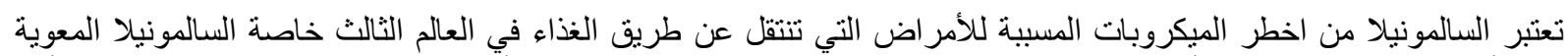

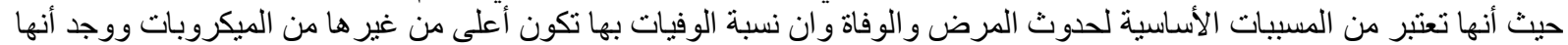

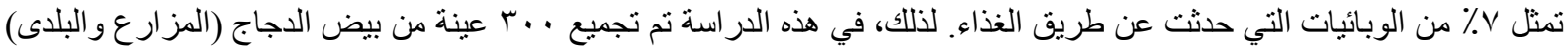

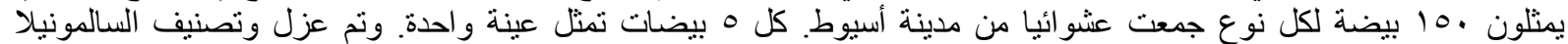

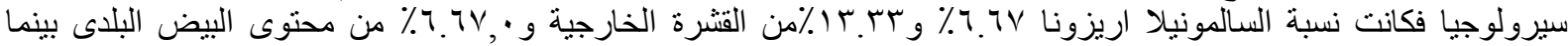

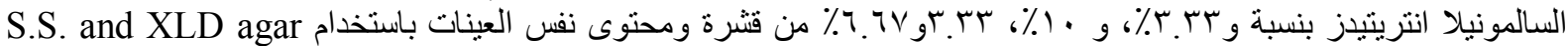

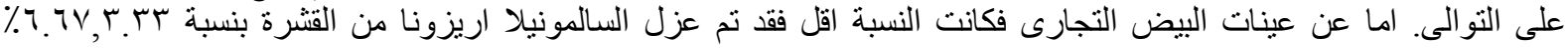

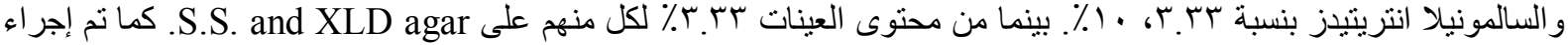

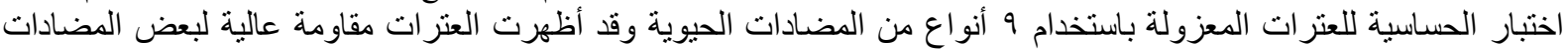

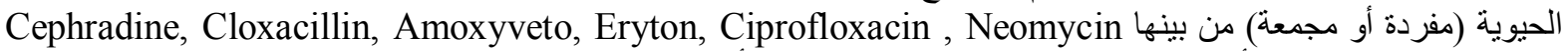

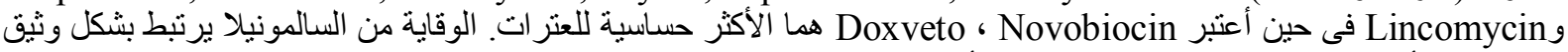

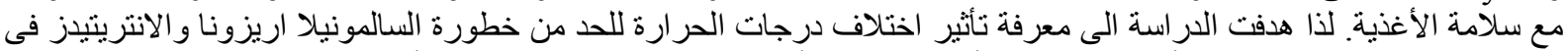

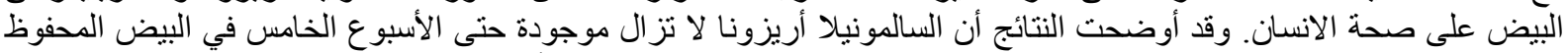

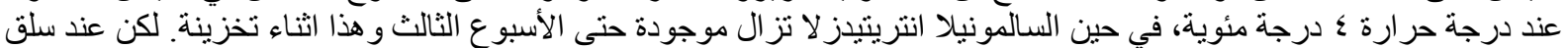

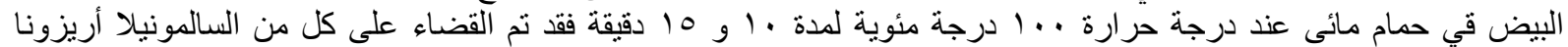
و انترينيدز . لذا يصنح بسلق البيض جيدا للقضاء على السالمونبلا وتجنب خطورتها. 